\title{
24. PALEOCLIMATIC SIGNIFICANCE OF SOME SEDIMENTARY COMPONENTS AT SITE 274
}

\author{
L.A. Frakes, Florida State University, Tallahassee, Florida
}

\section{INTRODUCTION}

Site 274 is important because it is the easternmost of sites on the continental rise (Sites 268,269, 274), and thus lies nearest to the holes drilled on the continental shelf in the Ross Sea (Sites 270-273 inclusive). Comparison of the sedimentation history of the rise versus that of the shelf is possible by detailed analyses of the respective cores. In this study, the gross lithologic changes and the abundances of carbonate, biogenic materials, ferromanganese micronodules, and sand are considered to reflect changes in the erosional and/or sedimentary regimes.

Five stratigraphic units are recognized above basalt at Site 274 . Units 1,3 , and 4 are composed primarily of gray, diatom-rich silty clay and/or claystone; Unit 2, within this envelope, differs in being yellow brown and containing common ferromanganese nodules. Unit 5 , at the base, contains few diatoms and is cherty in the upper part. The oldest definitely in situ ice-rafted clasts occur in Unit 2 (Core 12). (See Figure 1).

\section{SEDIMENTARY COMPONENTS}

Analyses were performed to determine the abundances of sand-size detritus, the biogenic component, ferromanganese micronodules, and carbonate. The procedure was as follows: the mainly siliceous fossils were floated off in heavy liquids of various densities, weighed, and expressed as a percentage of the total sample. A split of the original sample was used for determination of carbonate abundance by means of EDTA titration procedures. Next, the coarse fraction, larger than silt-size, was separated from the unfloated residue by sieving at $63 \mu$. This material was then passed through a Frantz magnetic separator to isolate the micronodule component. At this stage some difficulty was encountered in that ferromanganese-coated microfossils tended to separate with the magnetic micronodules. Hand-picking insured nearly complete separation into micronodule and biogenic components.

The results of the analyses are shown in stratigraphic sequence in Figure 1. It is apparent that silty clays of Units 1 and 2 differ greatly in their makeup from the older units. Above Core 13 there is an abrupt increase in the amount of sand and coarser material, and in the abundance of the micronodule and biogenic constituents. Carbonate abundance, on the other hand, shows little variation. The greatest changes take place within

'Present address: Monash University, Clayton, Victoria, Australia.
Core 12, with a gradual decrease in the abundance of each component in younger cores.

The coarse fraction is scant above Core 4 and is not present in significant proportions below Core 18, although rare grains are found down to Core 24 (Piper, this volume), and one short spurt ( $4 \%$ ) occurs in Core 28. It is likely from sand abundance that ice rafting at Site 274 did not commence before deposition of Core-18 materials. On this basis, granules and larger clasts found below Core 18 are regarded as probable "drillstones" dislodged from higher levels in the hole during drilling.

Ferromanganese micronodules, lacking below Core 18 , show their best development in Cores 10 through 12; that is, over the same interval occupied by the larger nodules and ferromanganese-cemented pebbles of Unit 2 . The comparative scarcity of micronodules above Core 9 is notable in that accumulation was relatively rapid here $(20-33 \mathrm{~m} / \mathrm{m} . \mathrm{y}$.$) . Regarding accumulation rates, a$ general slowdown seems to have begun as early as Core 19 but this is not reflected in increased content of micronodules. The slowdown may have been accompanied by subaqueous erosion which led to the development of at least one disconformity. Although such structures have not been detected visually, biostratigraphic considerations suggest the intervals between cores 11 and 12 and between 19 and 20 as likely positions.

Distribution of the biogenic component at Site 274 is similar to that of micronodules; there is a large concentration (3\%-6\%) in Cores 10 through 12 with decreases above and below. As with micronodules, abundance of the biogenic component seems inversely related to accumulation rate, and accordingly the dominant silt and clay contribution to the sediment must be the factor which varied substantially. Yet, the relatively high concentrations of sand-size material in the Core 10-12 interval are maintained at levels above Core 10 , where accumulation rates are high. This is taken to indicate that at about the time Core-12 materials accumulated, ice rafting began to contribute substantially to deposition, and continued so at least until deposition of Core 3 and younger sediments, even though the accumulation rate accelerated meantime (Core 10).

An interesting aspect of carbonate distribution at Site 274 is the complete lack of carbonate in the samples over the interval containing chert (Cores 36-39). This upper part of Unit 5 also apparently lacks a biogenic component, though the cherts themselves were not studied. It is possible that there is some causal relationship with alkalinity and salinity of interstitial water, as the highest values recorded at Site 274 are from samples in the cherty interval. However, it is not known whether cherts formed because large concentrations of fossil organisms 


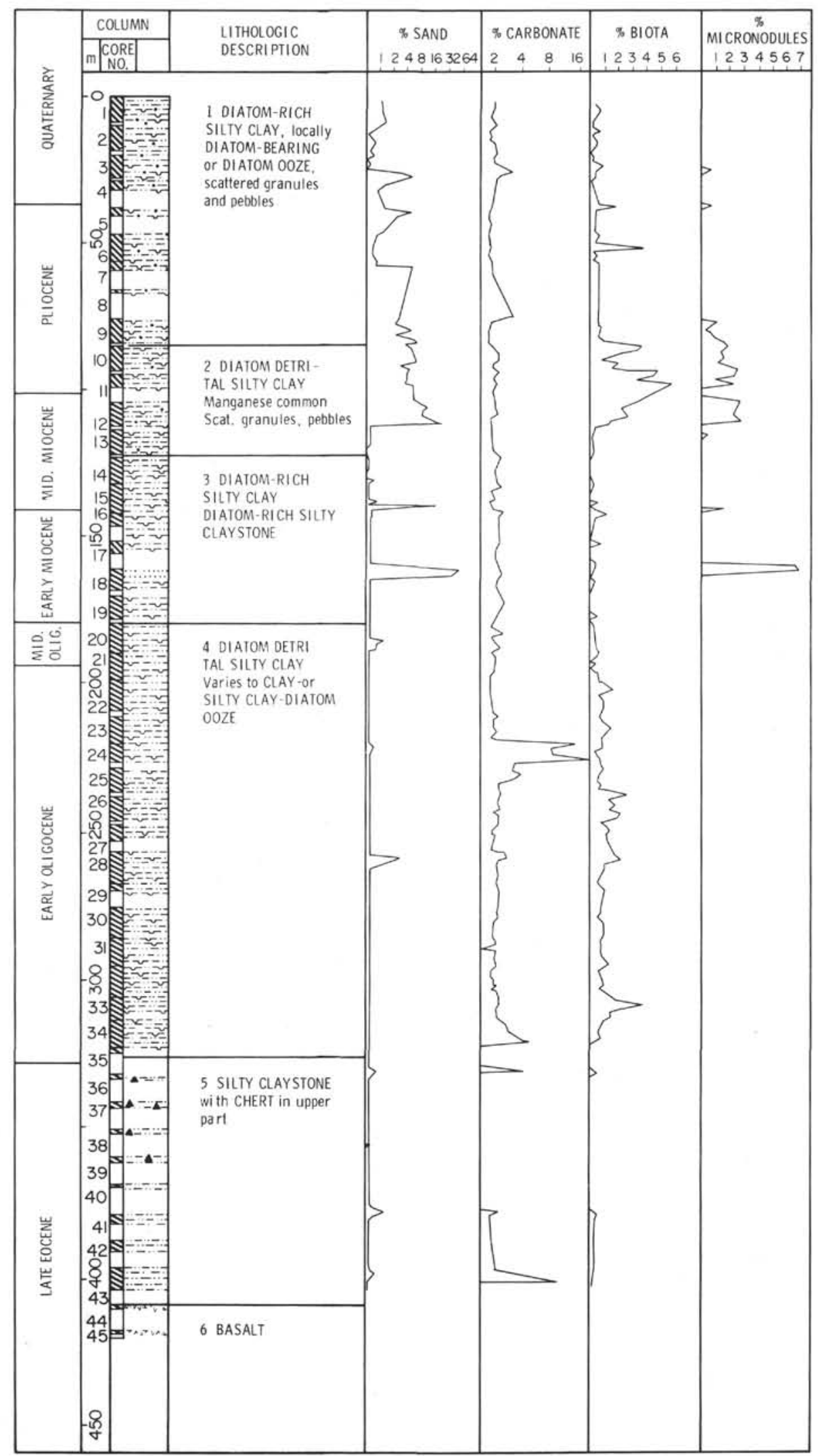

Figure 1. Analysis of sediments at Site 274. 
were present and could contribute to chert formation, or, alternatively, because chemical conditions in sediments originally lacking organisms were more suitable for chert development.

Kaolinite occurs in the fine fraction $(<2 \mu)$ above Core 21 at Site 274. This indicates that products of intensive chemical weathering, dating from a pre-middleOligocene time of soil formation in warmer and wetter conditions, are still being derived from the source area.

\section{CONCLUSIONS}

Rafting by ice of materials coarser than silt may have begun in the early Miocene (Cores 18,19) but probably not earlier. However, intensive ice rafting did not commence until at least the middle Miocene (Core 12), and it has tapered off considerably since deposition of Core- 4 materials (Pleistocene).

Units 2 and 3 at Site 274 represent an interval of extremely slow accumulation-generally between 2-11 $\mathrm{m} / \mathrm{m} . \mathrm{y}$.-during the Miocene and part of the early Pliocene. The increase in coarse detritus in Core 12, coming as it did at a time of slow accumulation ( $~ 2$ $\mathrm{m} / \mathrm{m} . \mathrm{y}$.), can perhaps best be explained by extensive reworking to form a lag deposit. The current activity at the time of reworking may have been related to an increase in vertical circulation caused by freezing at the base of ice shelves in the region, or it may represent more local events. The coarse debris, which continues in lesser abundance beyond Unit 2 into Unit 1, reflects the importance of ice rafting as an ongoing process in this environment.

Unit 2 at Site 274 shows remarkable attenuation. This sequence, Cores 10 through 13 inclusive, was deposited at an average rate of less than $3 \mathrm{~m} / \mathrm{m}$.y. in contrast to earlier and later rates in excess of $10 \mathrm{~m} / \mathrm{m}$.y. Active bottom currents apparently continuously winnowed most, if not all, of the Unit 2 sequence. Currents were in operation at the site in the early Pliocene, ceasing their strong erosion shortly after deposition of Core 10 materials. The time of their initiation cannot be stated definitely except to say that it was within the middle Miocene. This suggests that the strongly scouring currents postdated initiation of sea level glaciation in the Ross Sea in the late Oligocene.

Another biostratigraphic hiatus, between Cores 19 and 20 (?early Miocene overlying middle Oligocene) may represent strong current activity which coincides with the birth of the Ross Ice Shelf (?early Miocene). If this is the case, as is likely, icebergs did not contribute significant amounts of sand or gravel to this locale, nor were conditions suitable for growth of micronodules.

The early Pliocene date for termination of strong current activity possibly marks the major expansion and consequent breakup of the ice shelf which is proposed to explain the truncation of the Ross Sea sedimentary sequence. Expansion of the Ross Ice Shelf would thus have taken place shortly before or during deposition of Core-10 materials and while bottom currents were still active at Site 274. The retreat of the ice shelf, by this hypothesis, would result in diminution of current activity in the early Pliocene.

The proposed sequence of events is as follows:

1) Late Oligocene. Initiation of Ross Ice Shelf. Deposition of diatom clays at Site 274 (Unit 4).

2) Late Oligocene to ?early Miocene. Growth of Ross Ice Shelf. At some critical stage, probably early Miocene, extremely active bottom currents strip Site 274 sediments down to the middle Oligocene.

3) ?early Miocene to early middle Miocene. Slow accumulation of diatom clays of Unit 3 at Site 274. Little ice rafting.

4) Middle Miocene. Owing to initiation of strong bottom currents, marked decrease in rate of accumulation at Site 274 (Core 13) followed shortly by increases in ice rafting, biogenic accumulation, and ferromanganese micronodule growth (Core 12).

5) Middle Miocene to early Pliocene. Strong bottom currents continue to winnow sediments.

6) Early Pliocene (3.7-4.0 m.y.). Rapid expansion of Ross Ice Shelf? Sedimentation rate increases greatly (Core 11).

7) Pliocene (3.0-3.2 m.y.). Breakup of Ross Ice Shelf? Bottom currents diminish. Micronodule growth and biota accumulation decrease greatly (Core 9 ).

8) Pliocene-Pleistocene. Gradual decrease in ice rafting followed by marked decrease (Core 3 ). 